Hydrology and Earth System Sciences, 4(3), 439-449 (2000) (C) EGS

\title{
Hydrological characterisation of stalagmite dripwaters at Grotte de Villars, Dordogne, by the analysis of inorganic species and luminescent organic matter
}

\author{
Andy Baker ${ }^{1}$, Dominique Genty ${ }^{2}$ and Ian J. Fairchild ${ }^{3}$ \\ ${ }^{1}$ Department of Geography, University of Newcastle, Newcastle-upon-Tyne, England, NE1 7RU, UK \\ ${ }^{2}$ CNRS, Universite de Paris-Sud, UMR 8616, Laboratoire d'Hydrologie et de Geochimie Isotopique, Bat. 504, F 91405 Orsay Cedex, France \\ ${ }^{3}$ School of Earth Sciences and Geography, Keele University, Staffordshire, ST5 5BG, UK \\ e-mail for corresponding authors: andy.baker@ncl.ac.uk; dgenty@geol.u-psud.fr; i.j.fairchild@keele.ac.uk
}

\section{Abstract}

Five stalagmite drip-waters in the Grotte de Villars, Dordogne, have been monitored from early 1997 to early 1998, for variations in discharge, major inorganic species and dissolved luminescent organic matter. When compared to surface precipitation, each dripwater has a subtly different response, both in terms of discharge variability and lag time between surface precipitation and drip rate response. Calculated water excess is shown to be important in determining drip-water discharge; during periods of soil moisture deficit, drip-waters either show no response to surface precipitation, or in the case of one sample station, respond only to high intensity and/or high quantity precipitation events.

All drip-waters have a large storage component to their flow. Four sample stations have a similar hydrochemical and luminescence response, although the precise timing and magnitude of the responses may vary between drip sources that are $<5 \mathrm{~m}$ apart. Dripwater luminescence intensity increases in winter and spring, and increases in discharge lag by 2-3 months, suggesting that the water in the rising limb and peak of the winter discharge comes from the stored groundwater component rather than a soil source. Dripwater strontium anti-correlates with luminescence and exhibits a strong $( \pm 100 \%)$ seasonal variation, with high-strontium waters derived from stored groundwater and is inferred to originate in localised Sr-rich primary components in the limestone.

Drip-water conductivity reflects $\mathrm{Ca}-\mathrm{HCO}_{3}$ variations and falls during late summer to autumn, which is inferred to result from increased calcite precipitation above the cave with enhanced degassing related to progressive drying of the aquifer. Drip-water magnesium (following removal of the marine aerosol component) is just above detection limits and does not show strong seasonal variations. Variations in solution $\mathrm{PCO}_{2}$ occur, with a particularly strong increase in early 1997 . The various chemical trends are observed at a number of different sites despite a pronounced variation between them in terms of total $\mathrm{Ca}-\mathrm{HCO}_{3}$ mineralisation and $\mathrm{PCO}_{2}$.

One sampling station of the five investigated had a different response to surface precipitation; drip discharge was more variable, with evidence of non-linear responses, and luminescence intensity exhibited a dilution response to drip rate. For this site, flow switching occurred at times of high rainfall, with a rapid discharge response less than 24 hours after rainfall.

Luminescence intensity, inorganic chemistry, and discharge characteristics at the site are compared with results published from other cave systems; significant inter-site variability depends on the geology, depth of sample sites and extent of karstification. This suggests that the interpretation of stalagmite luminescence, and variations in $\mathrm{Sr}, \mathrm{Ca}$ and $\mathrm{Mg}$ must be considered on a site by site basis.

Keywords: stalagmite; dripwaters; luminescence; discharge; major ion chemistry

\section{Introduction}

Research interest in the geochemistry and hydrology of cave dripwaters has increased in recent years (Baker et al., 1997, 1999; Baker and Barnes, 1998; Bar-Matthews et al., 1997; Genty and Deflandre, 1998; Fairchild et al., 2000) due to the increased attempts to utilise Holocene stalagmites as palaeoclimatic and palaeoenvironmental proxies (Dorale $e t$ al., 1992; Genty et al., 1997; Tan et al., 1997; Holmgren et al., 1999; Baker et al., 1999; Bar-Matthews et al., 1999). Geochemical proxies contained within stalagmites vary frequently between individual samples that have been deposited at the same time period, both between cave systems and within the same cave (Genty, 1992, 1993; Smart et al., 1996; McDermott et al., 1999; McGarry and Baker, 2000), due to the natural variability and complexity of groundwater flow in karst aquifers (Gunn, 1981; Williams, 1983; Atkinson, 1985; Smart and Friederich, 
1987). Therefore, an essential prerequisite for the interpretation of these geochemical proxies is an understanding of contemporary stalagmite dripwater geochemical and hydrological variations. Ideally, monitoring should be undertaken over several years, and recent improvements with automatic sampling technology make this possible (Genty and Deflandre, 1998), though most studies have focused on a single hydrological year.

This paper presents data from five drip-water sampling stations in the Grotte de Villars, Dordogne from a monthly sampling programme in 1997-1998. The hydrological and geochemical parameters of particular interest are magnesium, strontium and calcium ion concentrations, luminescence intensity and wavelengths, and their relationships to drip discharge and surface precipitation and water excess. $\mathrm{Mg} / \mathrm{Ca}$ and $\mathrm{Sr} / \mathrm{Ca}$ ratios in stalagmites vary seasonally (Roberts et al., 1998; Huang et al., 2001) and provide, potentially, a proxy of relative groundwater residence time. Studies of cave waters in two other European caves have suggested that both $\mathrm{Sr} / \mathrm{Ca}$ and $\mathrm{Mg} / \mathrm{Ca}$ increase with increasing residence time (Fairchild et al., 2000). Dripwater calcium ion concentration is an important determinant of stalagmite growth rate (Dreybrodt, 1980, 1981; Baker et al., 1998a), but the influence of any changes in $\mathrm{PCO}_{2}$ in the cave and their effect on carbonate saturation must also be taken into account. Variations in luminescence intensity were also investigated as some cave sites exhibit seasonal variations in luminescence intensity (Baker et al., 1997; Baker et al., 1999) that can lead to the preservation of annual luminescence laminae in the associated stalagmites (Baker $e t$ al., 1993; Shopov et al., 1994). Variations in luminescence wavelength are observed in stalagmites and also provide a palaeoenvironmental proxy (Baker et al., 1998b; McGarry and Baker, 2000). Subsequent to the sampling programme presented here, several Holocene stalagmites have been sampled from the cave, whose geochemical variations it is hoped to interpret from an understanding of the hydrology and geochemistry of contemporary dripwaters. In addition, two sampling stations studied here in detail have been connected to an automatic sampling station measuring electrical conductivity and drip rate every 10 minutes. Monitoring of these sites has continued after the sampling period described here.

\section{Site description}

Grotte de Villars, Dordogne, France $\left(45^{\circ} 30^{\prime} \mathrm{N} 0^{\circ} 50^{\prime} \mathrm{E}\right.$, $175 \mathrm{~m}$ altitude) is a cave system, approximately $13 \mathrm{~km}$ in length, comprising both active and relict vadose and phreatic passages at depths of up to $50 \mathrm{~m}$ below the ground surface. Villars cave is developed mostly in Jurassic (Bajocian) limestone, locally (on the highest ground) covered by a few metres of Bathonian limestones. The Bajocian limestones are oolitic, with white ooids 0.2 to $1 \mathrm{~mm}$ in diameter. Filled fractures, which appear brownish due to iron staining in some places, can be seen. The Bathonian limestones are microcrystalline with some local oolitic strata, with smaller ooids than in the Bajocian limestone. The contact between Bajocian and Bathonian was observed at the nearby Cluzeau Quarry (less than $1 \mathrm{~km}$ from the cave), but was not directly exposed inside the cave. Cave location and survey are presented in Fig. 1. The cave is overlaid by woodland that comprises oak, hazel and juniper (Genty and Massault, 1997). At all locations, the soil cover is thin, comprising less than $20 \mathrm{~cm}$ of brown earth soil with occasional weathered clasts of limestone. The climate of the site is that of temperate maritime; monthly climate data are presented in Fig. 2 for the nearby WMO accredited meteorological station at Nontron $\left(45^{\circ} 32^{\prime} \mathrm{N} 0^{\circ} 40^{\prime} \mathrm{E}\right)$ for the period 1995-1999, together with soil moisture excess as calculated using the method of Thornthwaite (1955). Mean annual temperature is $11.7^{\circ} \mathrm{C}$ with seasonal variations from $20-22^{\circ} \mathrm{C}$ in summer to $5-7^{\circ} \mathrm{C}$ in winter; mean annual precipitation averages $982 \mathrm{~mm}$ with a slight winter maximum.

Reconnaissance visits were undertaken over the period 1996-1997 to find a selection of sample stations that reflected as wide a range of flow regimes as possible given the limits of dripwater sampling (primarily the need to collect water quickly enough to prevent degassing). Subsequently, hydrological and geochemical data were collected from 5 sampling locations at monthly intervals over the period February 1997 to March 1998. The sampling period is shown in Fig. 2 and the sample stations in Fig. 1. Stations $1 \mathrm{a}$ and $1 \mathrm{~b}$ and $10 \mathrm{a}$ and $10 \mathrm{~b}$ are paired samples spaced 0.5 and $4 \mathrm{~m}$ apart respectively, and were selected to investigate the local variability of geochemistry and hydrology. Stations 1a and $1 \mathrm{~b}$ are $30 \mathrm{~m}$ below the surface and $150 \mathrm{~m}$ from the entrance, station 4 is about $20 \mathrm{~m}$ deep and $150 \mathrm{~m}$ from the entrance, and stations $10 \mathrm{a}$ and $10 \mathrm{~b}$ are $10-15 \mathrm{~m}$ deep and $40 \mathrm{~m}$ from the entrance. Relative humidity measured at the sites ranged from $92-100 \%$. Additionally, bedrock samples were taken at random locations both within and overlying the cave system.

\section{Experimental method}

The five sample sites were visited at monthly intervals. The discharge onto each site was determined by measuring the time between successive drips; a constant drip volume of $0.14 \mathrm{~cm}^{3}$ per drip was measured, similar to that reported elsewhere (Dreybrodt, 1988; Baker et al., 1998a). On each visit, two $30 \mathrm{ml}$ amber glass bottles were filled with dripwater. One bottle was used for luminescence analysis with a Perkin-Elmer Luminescence Spectrophotometer LS-50B, using $5 \mathrm{~nm}$ slits and excitation wavelengths from 270 to $400 \mathrm{~nm}$. Emission was detected at 350 to $550 \mathrm{~nm}$ and the maximum luminescence intensity and the excitation and emission wavelengths where this occurred, were recorded. Mean raman peak intensity of distilled water blanks was 




Fig. 1. Survey of Grotte de Villars, shoming sample stations.

measured to determine machine stability and as a standard to enable inter-laboratory comparison of results; it equalled 14.9 intensity units.
Upon arriving in the laboratory, the other bottle was filtered and analysed for $\mathrm{pH}$ (with an approximate error of $\pm 0.05-0.1$ units), conductivity $( \pm 1 \%)$ and alkalinity $( \pm 3 \%)$ 


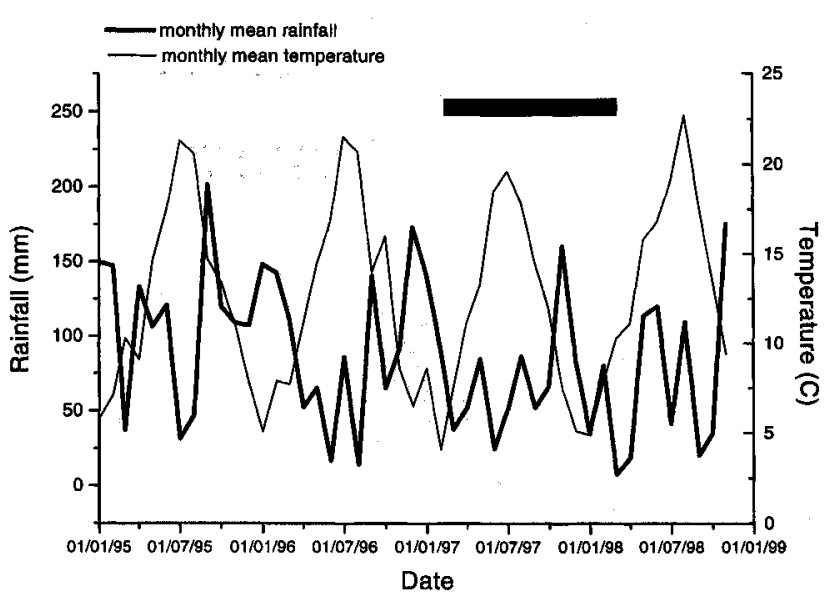

Fig. 2. Monthly rainfall and temperature at the nearby meteorological station of Nontron for the period 1995-1998. Bar shows the sampling period.

before preservation with 1 drop $\mathrm{HNO}_{3}$. Subsequently, major ion chemistry was determined by standard atomic absorption spectrometric techniques; nitrate, chloride and sulphate were determined using ion chromatography. Due to low water concentrations, strontium concentration was determined using a graphite furnace AAS, and magnesium concentration using ICP-AES. Typical analytical errors are $\pm 5 \%$, but, for $\mathrm{Mg}$, the low values encountered led to higher relative errors: comparison of duplicate analyses on different instruments indicated an absolute error of $\pm 0.45 \mathrm{mg} \mathrm{litre}^{-1}$. Charge balance errors (Table 1) are slightly positive because of a small proportion of highly positive balances. Comparison of measured conductivities with calculated (synthetic) conductivities derived from ionic compositions (Kiely, 1997) indicate that these unbalanced analyses resulted from values of $\mathrm{Ca}$ that were too high. Accordingly, a combination of charge balance and synthetic conductivity was used to produce balanced analyses from which saturation indices for calcite (the $\log$ of ionic activity product divided by solubility product for calcite) and solution $\mathrm{PCO}_{2}$ values were calculated using the speciation code PHREEQM (Appelo and Postma, 1993 ) with an overall error of \pm 0.15 units.

In addition to the monthly sampling, two sample stations (10a and $10 \mathrm{~b}$ ) were monitored automatically for variations in drip discharge as part of a longer-term project to analyse the inter-annual variations of discharge response. Drip rates were recorded as the mean number of drips every 10 minutes; surface rainfall and temperature were also recorded at the same time interval.

Bedrock samples were analysed for magnesium, strontium and calcium concentrations. Twelve samples were taken from both in-situ bedrock in the cave as well as large (3-10 cm diameter) clasts found within the soil profile. Approximately $50 \mathrm{mg}$ of bedrock powder was obtained by microdrilling, dissolved in dilute $\mathrm{HNO}_{3}$, diluted to $500 \mathrm{ml}$ and then filtered before being analysed by ICP-AES.
Duplicate analyses were obtained from individual bedrock clasts.

\section{Results}

Variations in surface temperature and rainfall for the sampling period are presented in Fig. 3. Water excess, calculated from monthly mean values, is also shown. Climatological data show a soil moisture deficit at the site up to April 1997, due to an exceptionally dry late winter, and again from June to October 1997, due to increased summer temperatures.

Variations in drip discharge for the $\mathbf{5}$ sites for the period 1997-1998 are presented in Figs. 4-5 and Table 1. Drip discharge results demonstrate that all drip sites maintain flow throughout the year, with mean drip rates between 0.05 and 0.6 drips $\mathrm{s}^{-1}$. When the monthly drip discharge data are considered, the coefficient of variation of discharge varies from $46 \%$ (site la) to $219 \%$ (site 4 ), and all sites can be classified as 'seasonal drips' except for site la ('seepage flow') (Baker et al., 1997). However, the analysis of the 10 minute automatically sampled data from sites $10 \mathrm{a}$ and $10 \mathrm{~b}$ suggests that monthly sampling does not reflect the true variability of high frequency drip discharge; coefficients of variation increased from $13 \%$ to $163 \%$ for site $10 \mathrm{a}$ and from $79 \%$ to $98 \%$ for site $10 \mathrm{~b}$ when 10 minute and 1 month sampling intervals were compared. All sites are, therefore, best classified as 'seasonal drips'. However, the maintenance of relatively high drip discharges without the seasonal drying of the drip source suggests that for all sites a significant proportion of flow has a storage source (Smart and Friederich, 1987). Data from site 10a show the presence of flow-switching at this site, with rapid and non-linear increases in drip rate (Fig. $5 \mathrm{c}$ ). For example, a rainfall event on the 5th May 1997 that deposited $8.2 \mathrm{~mm}$ in one hour generated a 6 hour duration recharge at station $10 \mathrm{a} 14$ hours later. A longer duration rainfall event on the 2nd July 1997 deposited $28.8 \mathrm{~mm}$ of rain over a 15 hour period and generated a similar recharge that lasted for two days with a lag of 13 hours. Similar events occurred within the wetting up period of October-December 1997.

Variations in luminescence intensity for all five sites are presented in Figs. 4d and 5d, together with drip discharge, and inorganic chemical data. For all sites except 10a, the luminescence intensity data demonstrate similar temporal trends, with an increase in March-July 1997, the precise timing of which varies between sites and is not resolvable given the 1 month sampling interval. Site 10a has a later luminescence peak than the other four sites (Fig. 5d), and the record appears to anti-correlate with drip discharge, suggesting that, at high flow conditions, the source of the dripwater is non-luminescent (e.g. a rapid fissure flow route with no overlying soil) or that significant dilution occurs. The different luminescence response at this station seems likely to be related to the non-linear flow-switching 
Table 1. Summary statistics for Grotte de Villars. Marine aerosol values calculated assuming all chloride is of the origin. Bold values for correlation are statistically significant at the $90 \%$ level.

\begin{tabular}{|c|c|c|c|c|c|c|c|c|c|c|}
\hline & \multicolumn{2}{|c|}{ Site la } & \multicolumn{2}{|c|}{ Site $1 b$} & \multicolumn{2}{|c|}{ Site 4} & \multicolumn{2}{|c|}{ Site $10 \mathrm{a}$} & \multicolumn{2}{|c|}{ Site $10 \mathrm{~b}$} \\
\hline & Mean & $\mathrm{SD}$ & Mean & $\mathrm{SD}$ & Mean & $\mathrm{SD}$ & Mean & $\mathrm{SD}$ & Mean & SD \\
\hline Discharge (drips $\mathrm{s}^{-1}$ ) & 0.05 & 0.02 & 0.26 & 0.20 & 0.58 & 1.28 & 0.24 & 0.32 & 0.09 & 0.07 \\
\hline $\mathrm{pH}$ & 7.21 & 0.16 & 7.26 & 0.18 & 7.34 & 0.27 & 7.44 & 0.16 & 7.47 & 0.19 \\
\hline Conductivity $(\mu \mathrm{S} / \mathrm{cm})$ & 471 & 35 & 549 & 37 & 476 & 71 & 354 & 20 & 340 & 30 \\
\hline $\mathrm{Ca}$ (mg/litre) & 138 & 18 & 175 & 27 & 144 & 28 & 124 & 35 & 107 & 19 \\
\hline $\mathrm{Mg}$ (mg/litre) & 2.2 & 0.3 & 2.1 & 0.1 & 1.7 & 0.3 & 0.9 & 0.2 & 0.9 & 0.1 \\
\hline $\mathrm{Na}$ (mg/litre) & 4.51 & 0.42 & 4.36 & 0.50 & 7.39 & 0.79 & 3.15 & 0.67 & 3.30 & 0.53 \\
\hline $\mathrm{Sr}(\mu \mathrm{mol} /$ litre $)$ & 1.90 & 1.00 & 1.70 & 0.94 & 1.90 & 1.13 & 1.39 & 1.36 & 1.36 & 1.11 \\
\hline $\mathrm{Sr} / \mathrm{Ca} * 1000$ (molar ratio) & 1.24 & 0.68 & 0.88 & 0.49 & 1.20 & 0.72 & 0.98 & 0.75 & 1.26 & 1.23 \\
\hline $\mathrm{K}$ (mg/litre) & 0.36 & 0.39 & 0.25 & 0.36 & 0.50 & 0.14 & 0.12 & 0.09 & 0.17 & 0.12 \\
\hline Alkalinity $\left(\mathrm{mg} / 1\right.$ as $\left.\mathrm{CaCO}_{3}\right)$ & 334 & 34 & 405 & 32 & 331 & 53 & 248 & 19 & 240 & 20 \\
\hline $\mathrm{Cl}$ (mg/litre) & 8.57 & 2.95 & 7.49 & 0.93 & 12.95 & 1.02 & 5.51 & 1.00 & 5.25 & 1.64 \\
\hline $\mathrm{SO}_{4}(\mathrm{mg} /$ litre $)$ & 4.79 & 1.82 & 5.14 & 2.39 & 6.22 & 3.34 & 6.15 & 2.70 & 4.94 & 2.24 \\
\hline $\mathrm{NO}_{3}$ (mg/litre) & 0.19 & 0.05 & 0.61 & 0.65 & 0.70 & 0.25 & 0.68 & 0.63 & 1.27 & 0.50 \\
\hline Charge balance (\%) & 2.0 & 5.1 & 2.5 & 7.5 & 3.6 & 8.9 & 8.1 & 13.5 & 4.1 & 8.6 \\
\hline$-\log \mathrm{PCO}_{2}$ (of balanced analyses) & 1.75 & 0.2 & 1.72 & 0.2 & 1.95 & 0.3 & 2.1 & 0.15 & 2.15 & 0.2 \\
\hline $\begin{array}{l}\text { Calcite saturation index (of balanced } \\
\text { analyses) }\end{array}$ & 0.2 & 0.15 & 0.4 & 0.15 & 0.35 & 0.2 & 0.2 & 0.2 & 0.25 & 0.2 \\
\hline $\mathrm{Na}$ (median \% from marine aerosol) & 106 & & 97 & & 98 & & 97 & & 85 & \\
\hline $\mathrm{Mg}$ (median \% from marine aerosol) & 23 & & 23 & & 50 & & 43 & & 34 & \\
\hline $\mathrm{Sr}$ (median \% from marine aerosol) & 2 & & 3 & & 5 & & 3 & & 3 & \\
\hline Luminescence intensity (units) & 119.0 & 73.5 & 92.7 & 77.9 & 103.4 & 105.1 & 57.6 & 53.8 & 37.7 & 53.9 \\
\hline $\begin{array}{l}\text { Luminescence emission wavelength } \\
(\mathrm{nm})\end{array}$ & 406.3 & 2.9 & 406.1 & 2.7 & 406.7 & 2.5 & 406.1 & 5.8 & 407.4 & 5.5 \\
\hline $\begin{array}{l}\text { Coefficient of variation of discharge } \\
\text { (monthly sampling: } 10 \text { min sampling in } \\
\text { brackets) }\end{array}$ & $46 \%$ & & $76 \%$ & & $219 \%$ & & $13 \%$ & $163 \%)$ & $79 \%(9$ & $8 \%)$ \\
\hline $\begin{array}{l}\text { Correlation (monthly discharge vs. } \\
\text { luminescence) and lag (months) }\end{array}$ & $0.9(3)$ & & $0.59(2)$ & & $0.41(3)$ & & -0.44 & & $0.89(3)$ & \\
\hline Timing of Sr increase & Sep-97 & & Sep-97 & & Jul-97 & & Sep-97 & & May-97 & \\
\hline
\end{tabular}

observed at the site. When compared to drip discharge, the luminescence intensity for the other sites demonstrates the best correlation with discharge with a lag of 2-3 months (Fig. 4c \& 4d); for sites $1 \mathrm{a}$ and $10 \mathrm{~b}$ the dischargeluminescence relationship is statistically significant (Table 1); these two sites are those with the lowest mean annual discharge.

Luminescence wavelength data demonstrate a strong similarity between sites (Table 1). All sites have a maximum excitation at $295 \mathrm{~nm}$, and emission wavelengths are identical (406-407 nm), reflecting the similarity of overlying soil and vegetation cover. Both excitation and emission wavelengths are comparatively low when compared to other cave waters from British cave systems (Baker and Genty, 1999). No seasonal trends are observed in luminescence wavelength, unlike those previously observed elsewhere (Brown's Folly Mine; Baker and Genty, 1999), where luminescence wavelength decreased during the autumn high luminescence intensity pulse. The lack of seasonality observed at Villars could be due to the low frequency of sampling, or to differences in chemical structure and the greater degree of humification of the organic acids at Villars.

Cation and anion data for all sample stations are presented in Table 1 with the most useful parameters plotted on Figs. $4 a, b$ and $5 a, b$. Calcium and alkalinity as bicarbonate dominate the waters; all other ions show little variation. 

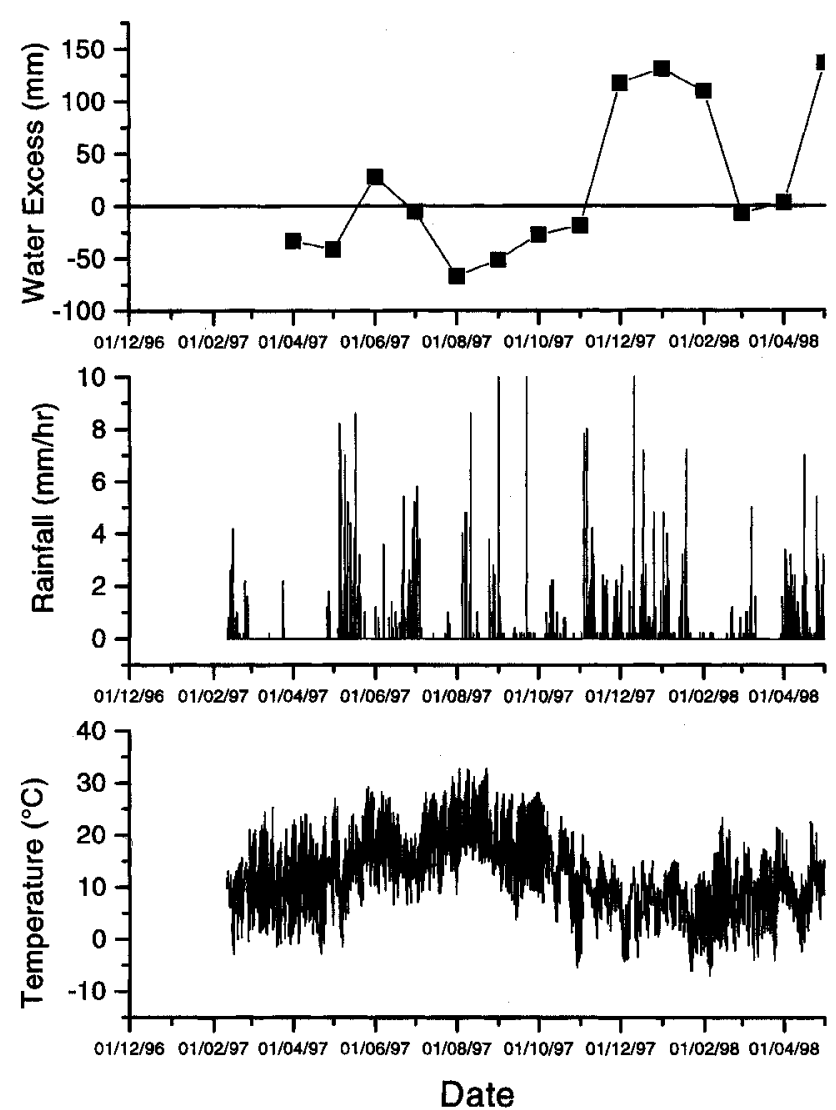

Fig. 3. Hourly rainfall and temperature data at the Grotte de Villars, together with mater excess calculated after Thornthmaite (1955).

Accordingly, the conductivity readings give the most precise indication of the variations in $\mathrm{Ca}-\mathrm{HCO}_{3}$ mineralization of the waters. The general pattern at sites $1 \mathrm{a}, 1 \mathrm{~b}, 4$ and $10 \mathrm{~b}$ is that conductivity rises in the spring and falls from August to November, rising thereafter. Site 10a displays a similar, but more muted change, although without initial low values. Initial $\mathrm{PCO}_{2}$ values are low (corresponding to high $\mathrm{pH}$ values) at all sites but peak in April. Subsequent variation is within errors at site 10 , but is slightly greater at sites 1 and 4 where overall declines in early summer and during the autumn are interrupted by a rise from July to August. The overall effect of changes in $\mathrm{pH}$ and $\mathrm{Ca}-\mathrm{HCO}_{3}$ mineralization on the saturation index is a steady fall through to November at site 10a, and an initial fall to March at the other sites followed by more limited variations which are within the calculated errors. The absolute levels of $\mathrm{PCO}_{2}$ and of $\mathrm{Ca}-\mathrm{HCO}_{3}$ are much lower at sites $10 \mathrm{a}$ and $10 \mathrm{~b}$ than at the other sites.

The trace elements $\mathrm{Mg}$ and $\mathrm{Sr}$ can be used to trace water-rock interactions, but correction for atmosphericallyderived ions is advisable (Fairchild et al., 2000). No rainwater chemistry data are available at Villars, but an estimate of the marine aerosol component of atmospheric precipitation can be obtained by the ratio of $\mathrm{Na}$ ions to $\mathrm{Cl}$, the dominant species in seawater. Although excess $\mathrm{Cl}$ can be derived from industrial activity in France (Negrel and Roy, 1998), the median calculated values for the percentage of $\mathrm{Na}$ in the Villars water analyses representing marine aerosol are close to $100 \%$ (Table 1), corresponding to a seawater $\mathrm{Na} / \mathrm{Cl}$ ratio. Marine contributions to $\mathrm{Ca}$ are negligible and they are small for $\mathrm{Sr}(2-5 \%$, Table 1). However, for $\mathrm{Mg}$ they are $23-50 \%$.

The temporal variation in $\mathrm{Sr}$ at Villars is striking; a substantial increase occurs during the autumnal decline in drip rates at all sites but there is no return to low values by the end of the sampling period. The mean molar $\mathrm{Sr} / \mathrm{Ca}$ ratios in bedrock and soil clasts are $0.15 \pm 0.06 \times 10^{-3}$ which are matched quantitatively by the low spring-summer values of $\mathrm{Sr}$ encountered at sites $10 \mathrm{a}$ and $10 \mathrm{~b}$; all other values are higher, with mean values typically an order of magnitude higher (Table 1), which suggest an additional $\mathrm{Sr}$ source. For $\mathrm{Mg}$, once corrections have been made for marine aerosol contributions, the temporal variation is just above or within the measurement errors (depending on the site), but a substantial rise of the type displayed by $\mathrm{Sr}$ can be ruled out. The bedrock $\mathrm{Mg} / \mathrm{Ca}$ molar ratios in bedrock and soil clasts, $8.1 \pm 3.4 \times 10^{-3}$, which compares with the marine aerosol-corrected values for Villars dripwaters which range from 6 to $12 \times 10^{-3}$. No additional $\mathrm{Mg}$ source is thus required.

\section{Interpretation}

Comparison of the drip discharges and climate data demonstrate that the presence of a soil moisture deficit limits the recharge to the cave. For example, auto-sampling of stations $10 \mathrm{a}$ and $10 \mathrm{~b}$ demonstrate that the relatively low rainfall totals in February 1997, when compared to rainfall in May and June, had a greater effect on drip discharge due to the water excess at the former time (Figs. $4 \mathrm{c}$ and $5 \mathrm{c}$ ). Sites $10 \mathrm{a}$ and $10 \mathrm{~b}$ also demonstrate seasonal variations in the lag between drip discharge and surface rainfall. In late winter and spring of the 1996-1997 hydrological year, there is a more rapid response than that of the autumn of the 19971998 year, where there is a lag of 1 month from the first soil moisture excess.

Measurement of luminescence intensity and wavelength suggest that the first water transported when drip discharge increases in late autumn is water that has been resident in the karst aquifer. It takes some 2 months for the soil-derived water to reach the cave void, suggesting a piston-flow effect as well as a long groundwater residence time such as might be expected given diffuse flow through $10-30 \mathrm{~m}$ of oolitic limestone. A lag between discharge increase and tuminescence increase was also observed at Brown's Folly Mine, England, where the lag varied between 10 and 30 days for drip sites at c. $10 \mathrm{~m}$ depth (Baker et al., 1999). However, no lag was observed in Lower Cave, England, in a previous study from a shallow depth but in strongly dipping, thickly bedded Carboniferous limestone that may have higher 

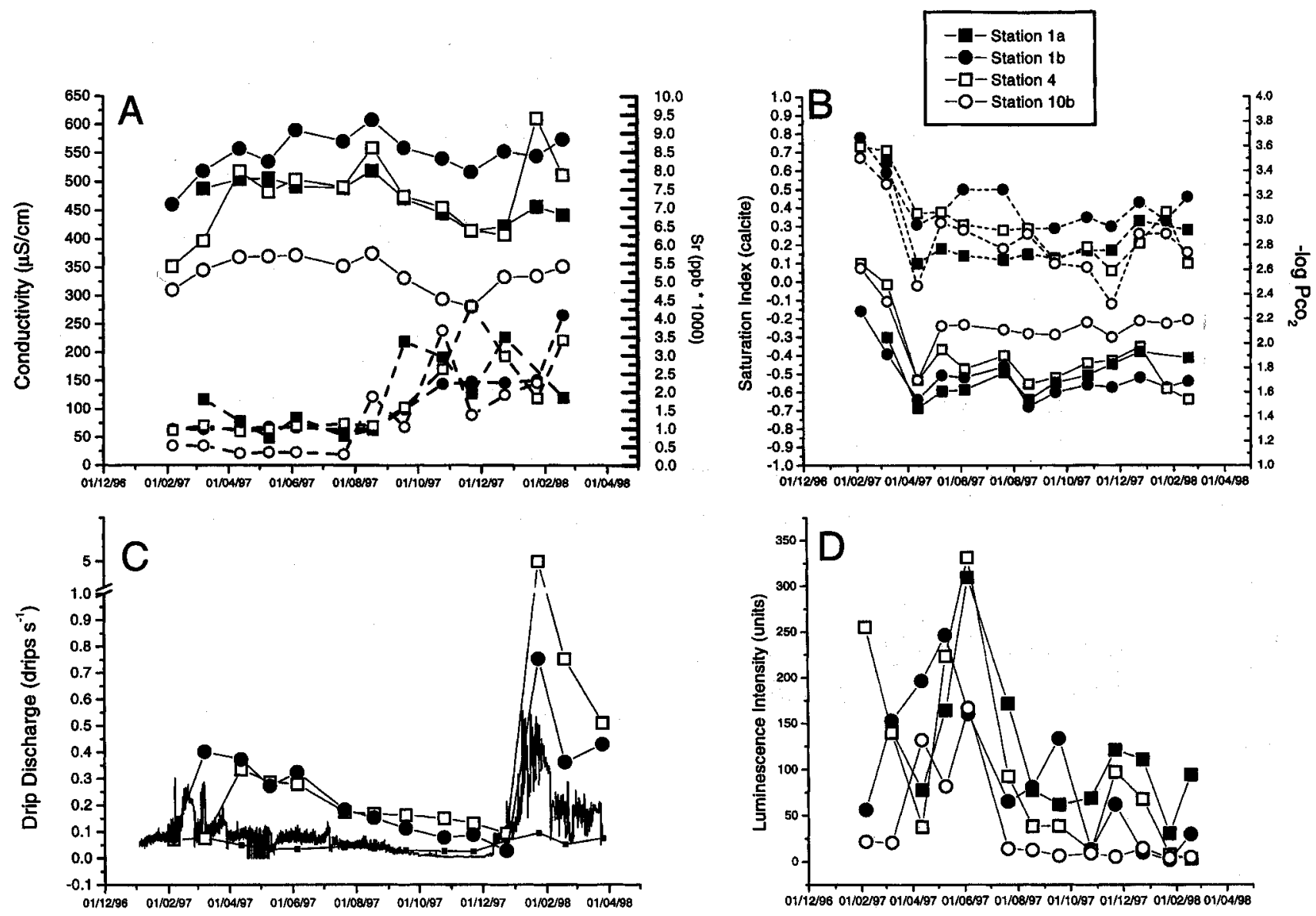

Date

Fig. 4. Variations for sample stations $1 \mathrm{a}, 1 \mathrm{~b}, 4$ and $10 \mathrm{~b}$ in: (a) conductivity (solid) and $\mathrm{Sr}$ (dashed), (b) calculated aqueous $\mathrm{PCO}_{2}$ (solid) and saturation index for calcite (dashed); errors of \pm 0.15 are not shomn for clarity, $(c)$ drip discharge, and (d) luminescence intensity.

transmissivity (Baker et al., 1997). Comparison of several cave sites demonstrates significant inter-site variability depending on the geology, depth of sample sites and extent of karstification.

The relatively slow drip discharge sites have the best lagged correlation of luminescence intensity with the drip discharge. A high discharge $\left(0.015 \mathrm{ml} \mathrm{s}^{-1}\right)$ site at Lower Cave, England has previously been demonstrated (Baker and Barnes, 1998) to have a worse correlation with discharge due to a greater proportion of non-linear responses to surface precipitation. Sites $1 b, 4$ and $10 a$ at Villars all have a higher discharge than this, and $10 \mathrm{a}$ demonstrated non-linear flow variations; a simple model of diffuse flow through the relatively porous and homogenous oolitic limestone is unlikely to explain the observed luminescence data. Stations 1a and 10b have the lowest mean discharge and best correlation between discharge and luminescence intensity; for these sites, slow porous flow and stored water are likely to be dominant. For stations 4 and $\mathrm{lb}$, the fissure flow component becomes increasingly important; for station 10a, it is important and also affects flow non-linearly.
In general, variations in dissolved $\mathrm{Ca}$ may be due to dilution effects, to variations in $\mathrm{CaCO}_{3}$ dissolution (mainly in the soil zone, Pitty, 1971), or to varying amounts of prior calcite precipitation in the aquifer above the drip site (Fairchild et al., 2000). The autumnal drop in Ca during a period of steadily declining dripwater fluxes rules out dilution effects, whilst its rise during wetter periods, long before any increase in the soil-derived luminescence signature, argues against a direct link to soil Ca values. Instead, increased amounts of prior calcite precipitation may have occurred during the autumn because of the development of air pockets in the aquifer allowing degassing to occur more extensively above the cave.

Removal of Ca by the prior precipitation of calcite would lead to an increase in $\mathrm{Mg} / \mathrm{Ca}$ and $\mathrm{Sr} / \mathrm{Ca}$ in drip waters and calcite precipitates of up to $25 \%$ during the autumn. Negligible effect on aqueous $\mathrm{Mg}$ and $\mathrm{Sr}$ would be expected because of the low values $(<0.1)$ of the partition coefficients (K) for $\mathrm{Mg}$ and $\mathrm{Sr}$ in calcite where: $\mathrm{K}_{\mathrm{Mg}}=\left(\mathrm{Mg} / \mathrm{Ca}_{\text {solution }}\right) /$ $\left(\mathrm{Mg} / \mathrm{Ca}_{\text {calcite }}\right)$ and likewise for $\mathrm{Sr}$. The prior precipitation effects are masked by analytical resolution in the case of 

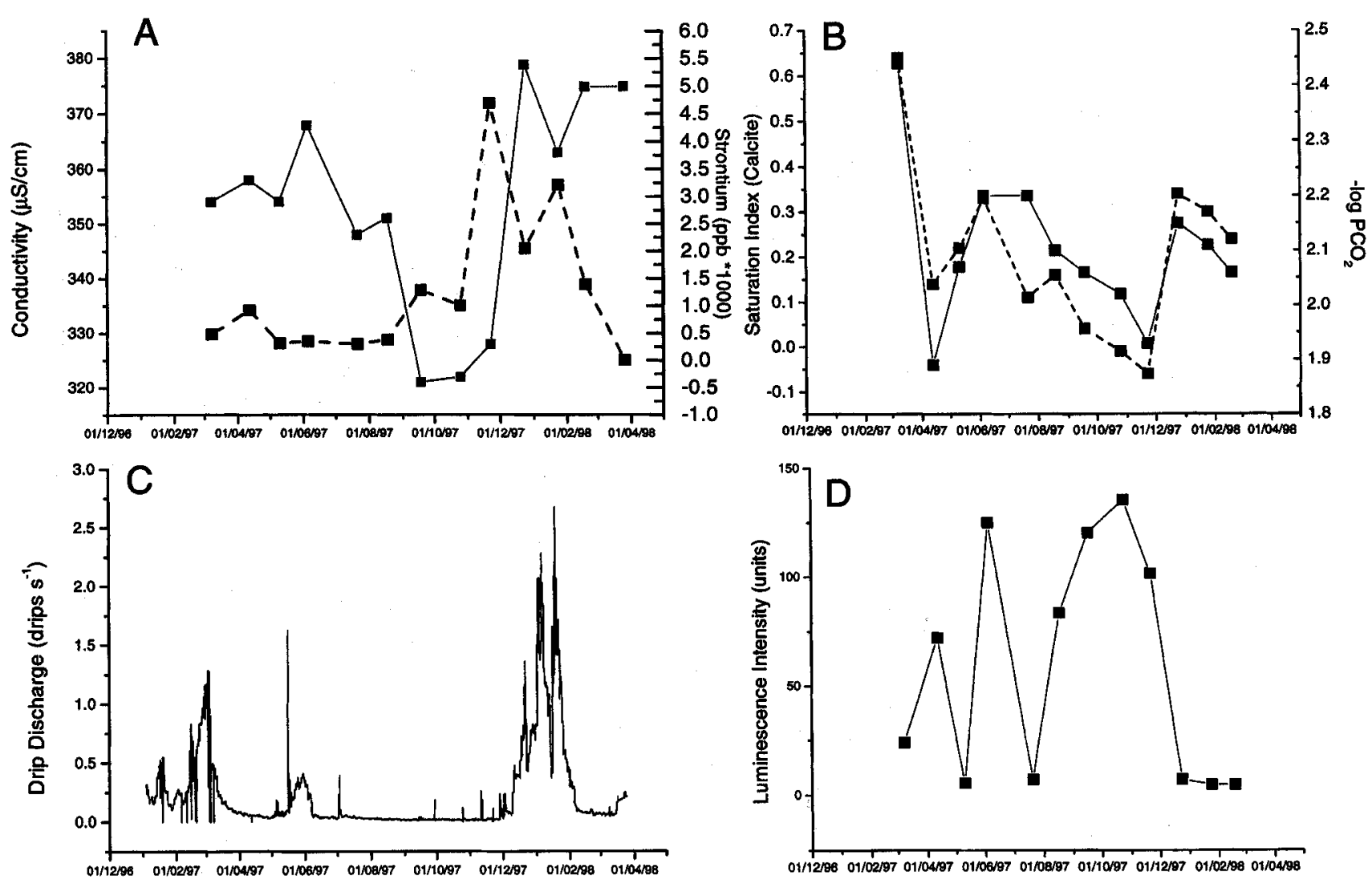

Date

Fig. 5. Variations for sample station 10a in: (a) conductivity (solid) and Sr (dashed), (b) calculated aqueous $P_{\mathrm{CO}_{2}}$ (solid) and saturation index for calcite (dashed); errors of \pm 0.15 are not shown for clarity, (c) drip discharge, and (d) luminescence intensity.

aqueous $\mathrm{Mg}$, but should be clearly resolvable in ion microprobe speleothem analysis of $\mathrm{Mg}$ which is directly controlled by solution $\mathrm{Mg} / \mathrm{Ca}$, (Huang et al., 2001). In the case of $\mathrm{Sr} / \mathrm{Ca}$, the prior precipitation effects are presumably overwhelmed by the independent increase in $\mathrm{Sr}$ in solution. The most likely source of excess $\mathrm{Sr}$ is from the remains of originally aragonitic skeletal debris, rich in $\mathrm{Sr}$, which are commonly found within calcitized fossils in Jurassic limestones (Sandberg and Hudson, 1983) and are particularly likely to be present in low-permeability layers as the aragonitic fossils tend to be completely dissolved away in high-permeability grainstone lithologies. Such materials were not represented in the bulk limestone samples analysed. The rise in $\mathrm{Sr}$ at each site is consistent with the increased importance of a low-permeability $\mathrm{Sr}$-rich water source. Hysteresic behaviour is displayed such that entrainment from these Sr-rich sources continued to the end of the sampling period.

The $\mathrm{PCO}_{2}$ values of the waters will depend on: 1 ) the primary $\mathrm{PCO}_{2}$ of the infiltrating waters, which will be influenced strongly by high $\mathrm{PCO}_{2}$ in soil zones (Pitty, 1971): 2) buffering by any reservoir of $\mathrm{CO}_{2}$ in the aquifer (Atkinson, 1977): and 3) the degree of degassing. Ventila- tion effects may limit the latter particularly if there are large effluxes of $\mathrm{CO}_{2}$-rich water into a cave. In the absence of measurements of soil and cave air $\mathrm{PCO}_{2}$ values, it is not possible to interpret the spatial or temporal variation in Villars data unequivocally. However, temporal variations in $\mathrm{PCO}_{2}$ complicate the link between $\mathrm{Ca}$ concentration and saturation index (Figs. 4b and 5b), or between $\mathrm{Ca}$ concentration and predicted growth rate as in the model of Dreybrodt (1988), (see also Baker et al., 1998a). Overall, the effects of varying $\mathrm{PCO}_{2}$ will enhance the variability of growth rate with time. The late summer to autumn season in 1997 will be relatively poorly represented by speleothem growth because of low drip rates and of lower $\mathrm{Ca}$ values (related to prior calcite precipitation) variably enhanced at site $10 \mathrm{a}$ and offset at sites $1 \mathrm{a}, \mathrm{lb}$ and 4 by $\mathrm{PCO}_{2}$ changes. Conversely, the early part of the monitoring period will show maximal growth rates reflecting high drip rates, low $\mathrm{PCO}_{2}$ and high Ca.

Predictions of the characteristics of the calcite growth during the monitoring period are: 1) an initial pure fastgrowing calcite that subsequently becomes more luminescent during the summer; 2) a slower growing calcite in the autumn with low luminescence (except at site 10a), but 
increases in $\mathrm{Mg}$ and especially in $\mathrm{Sr}$; 3) faster winter growth with lower $\mathrm{Mg}$ and low luminescence but $\mathrm{Sr}$ continuing to be high. This record would be much more disturbed by short-term events at hydrologically-sensitive sites such as 10a. The predictions, while limited by the failure of the system in early 1998 to return to its state of a year previously, associate rising $\mathrm{Mg}$ and $\mathrm{Sr}$ with inferred drier conditions as in the ion microprobe records of Roberts et al. (1998) and Huang et al. 2001. However, in detail, the records reflect both source and hydrological controls that must be understood on a site-specific basis.

\section{Concluding discussion}

Inorganic chemical data suggest that three flow components are important in the drip-waters at Villars. Firstly, a long residence time component derived from a low-permeability source comprises old stored water that has high $\mathrm{Sr} / \mathrm{Ca}$ and low luminescence. Secondly, flushing of surface water into the limestone at times of soil moisture excess transports water that has high calcium, low $\mathrm{Sr} / \mathrm{Ca}$ and high luminescence intensity; given the lagged response between luminescence and drip discharge, this has a relatively long residence time, although it may also have a fissure flow component. Thirdly, some water at station $10 \mathrm{a}$ has more variable chemical and luminescent properties and exhibits flow-switching behaviour, depending on the extent (if any) of contact with other soil and groundwater, which will in turn depend on the time of year and intensity and amount of surface rainfall.

Luminescence results demonstrate a relatively long lag between increasing discharge and luminescence intensity, reflecting the time taken to transport this soil derived water to $10-30 \mathrm{~m}$ depth in the karst aquifer. The inverse correlation of luminescence intensity with mean annual discharge suggests the increased importance of non-linear responses at high discharge sites. This could be due to an increasing dominance of fissure flow components with increasing discharge and increasing discharge variability, both of which may mix groundwaters of different residence times. Alternatively, the increasing importance of flowswitching and other non-linear effects, which will also affect the luminescence intensity signal by mixing waters of different ages, may explain the observations. Intra-annual luminescence intensity variations at Villars are greater than those observed at Lower Cave and Brown's Folly Mine, England (Baker et al., 1997; Baker et al., 1999) despite the lower sampling resolution in this study. Given the greater lag between drip discharge and luminescence in this study, which suggests a greater damping of the luminescence signal, this increased luminescence intensity probably demonstrates increased dissolved organic carbon in the drip-water. This may be because a high discharge at the site transports a greater proportion of high molecular weight luminescent carbon or, more likely, because of the thicker soil cover and warmer climate at Villars; both factors enhance the production rate and quantity of luminescent organic carbon. The worsening correlation between luminescence intensity and mean drip discharge also agrees with results presented by Baker and Barnes (1998). Hence, seasonal luminescence intensity fluctuations are most likely to be observed at sites of low mean annual discharge, yet also at those which have a seasonal variation in water supply. At Villars, such a mechanism is provided despite a lag between surface precipitation, drip discharge increase and luminescence intensity increase, suggesting that geochemically homogeneous waters are being transported within the aquifer.

Overall, the present results demonstrate the importance of understanding the dynamics of all aspects of the karst system from the soil through to the bedrock. Understanding is limited by the temporal limitations of monthly sampling, by lack of sampling of gaseous $\mathrm{PCO}_{2}$ and by the lack of return of the system to its initial state over a year after commencing sampling. Nevertheless, the present drip-water results have important implications for the analysis of stalagmites at the Villars cave site.

Stalagmites can be used as archives of fossil $\mathrm{Mg} / \mathrm{Ca}$, $\mathrm{Sr} / \mathrm{Ca}$ and luminescence variations and, hence, of geochemical and palaeoenvironmental changes over the past $10^{1}-10^{4}$ years. Drip-water luminescence results suggest that over annual timescales, luminescence intensity variations could show annual laminae in stalagmites. However, one would need to sample stalagmites with slow mean drip rates $\left(<0.05\right.$ drips s $^{-1}$ and low flow variability to avoid any nonlinear effects from fissure flow sources. However, even in these samples, laminae might not be preserved continuously if inter-annual climate variations affected drip rates; an increased drip rate might lead to non-linear luminescencedischarge effects as observed at site 10a. A decrease in drip rate might lead to a damping of the luminescence signal such that seasonal luminescence fluxes were smoothed; the lack of low discharge $\left(<0.01\right.$ drips $\left.\mathrm{s}^{-1}\right)$ sample sites make it impossible to validate this hypothesis. Variations in long term (>annual) luminescence intensity might be correlated with soil-dissolved organic carbon production and therefore also give a palaeoclimate signal which might, however, be complicated by dilution by high drip discharge sites. Luminescence intensity variations for low drip rate samples may yield useful palaeoclimate information if stalagmite luminscence intensity can be measured as a proxy whilst eliminating interference from porosity variations.

The inorganic data demonstrate that changes in $\mathrm{PCO}_{2}$ will cause bigger changes in speleothem growth rate than those predicted by aqueous $\mathrm{Ca}$ and drip rate variations alone. The data predict an asymmetric cycle during the sampling period; during progressively drier conditions in late summer through autumn, an increase in prior calcite precipitation causes speleothem $\mathrm{Mg}$ to rise as a result of an increase in solution $\mathrm{Mg} / \mathrm{Ca}$. Speleothem $\mathrm{Sr}$ would rise more extensively because of the input from low-perme- 
ability sources during low flow. Higher winter flow rates reverse the $\mathrm{Mg} / \mathrm{Ca}$ trend in Villars waters but high $\mathrm{Sr} / \mathrm{Ca}$ persisted throughout the remainder of the sampling period. If sampling had continued through the spring of 1998 , a fall in $\mathrm{Sr}$ could be predicted. Further research to understand the chemical trends over inter-annual time periods may be achieved through analysis of annually banded, recently deposited stalagmites at the cave; these may provide an archive of past $\mathrm{Mg} / \mathrm{Ca}$ and $\mathrm{Sr} / \mathrm{Ca}$ fluxes.

\section{Acknowledgements}

This paper was written whilst Andy Baker was funded on an exchange to Paris by the Royal Society. Water samples were analysed by the Chemical Analytical Services Unit at the University of Newcastle and by Jim Grapes at the Department of Geography, University of Exeter. Luminescence data was part-funded by the NERC, NATO, CNRS and the Royal Society. The authors thank H. Versaveau for access to the cave, CNRS VariENTe and GDR440 for funding. Early drafts of the manuscript were improved through discussions with Yemane Asmerom, and the comments of four anonymous referees.

\section{References}

Appelo, C.A.J. and Postma, D., 1993. Groundmater, Geochemistry and Pollution. Balkema, Rotterdam.

Atkinson, T.C., 1977. Carbon dioxide in the atmosphere of the unsaturated zone: an important control of groundwater hardness in limestones. 7. Hydrol., 35, 111-123.

Atkinson, T.C., 1985. Present and future directions in karst hydrogeology. Ann. Soc. Geol. Belgique, 108, 293-296.

Baker, A. and Barnes, W.L., 1998. Comparison of the luminescence properties of waters depositing flowstone and stalagmites at Lower Cave, Bristol. Hydrol. Process., 9, 1447-1459.

Baker, A. and Genty, D., 1999. Fluorescence wavelength and intensity variations of cave waters. 7. Hydrol., 217, 19-34.

Baker, A., Smart, P.L., Edwards, R.L. and Richards, D.A., 1993. Annual growth banding in a cave stalagmite. Nature, 364,518 520.

Baker, A., Barnes, W.L. and Smart, P.L., 1997. Stalagmite drip discharge and organic matter fluxes in Lower Cave, Bristol. Hydrol. Process., 11, 1541-1555.

Baker, A., Genty, D., Dreybrodt, W., Grapes, J. and Mockler, N.J., 1998a. Testing theoretically predicted stalagmite growth rate with recent annually laminated stalagmites: implications for past stalagmite deposition. Geochim. Cosmochim. Acta, 62, 393404.

Baker, A., Genty, D. and Smart, P.L., 1998b. High-resolution records of soil humification and palaeoclimate change from speleothem luminescence excitation-emission wavelength variations. Geology, 26, 903-906.

Baker, A., Proctor, C.J. and Barnes, W.L., 1999. Variations in stalagmite luminescence laminae structure at Poole's Cavern, England, AD1910 to AD 1996: calibration of a palaeoprecipitation proxy. Holocene, 9, 683-688.

Bar-Matthews, M., Ayalon, A., Matthews, A., Sass, E. and Halicz, C., 1997. C and $O$ isotope study of the active water-carbonate system in a karstic Mediterranean cave: implications for palaeoclimate research in semi-arid regions. Geochim. Cosmochim. Acta, 60, 337-347.

Bar-Matthews, M., Ayalon, A., Kaufman, A. and Wasserburg, G.J., 1999. The Eastern Mediterranean palaeoclimate as a reflection of regional events: Soreq cave, Israel. Earth Planet. Sci. Lett., 166, 85-95.

Dorale, J.A., Gonzalez, L.A., Reagan, M.K., Pickett, D.A., Murrell, M.T. and Baker, R.G., 1992. A high-Resolution Record of Holocene Climate Change in Speleothem Calcite from Cold Water Cave, Northeast Iowa, Science, 258, 16261630 .

Dreybrodt, W., 1980. Deposition of calcite from thin films of natural calcareous solutions and the growth of speleothems. Chem. Geol., 29, 89-105.

Dreybrodt, W., 1981. The kinetics of calcite deposition from thin films of natural calcareous solutions and the growth of speleothems: revisited. Chem. Geol., 32, 237-245.

Dreybrodt, W., 1988. Processes in Karst Systems. Springer-Verlag, Berlin, 288 pp.

Fairchild, I.J., Borsato, A., Tooth, A.F., Frisia, S., Hawkesworth, C.J., Huang, Y., McDermott, F. and Spiro, B., 2000. Controls on trace element ( $\mathrm{Sr}-\mathrm{Mg}$ ) compositions of carbonate cave waters: implications for speleothem climatic records. Chem. Geol., 166, 255-269.

Genty, D., 1992. Les spéléothèmes du tunnel de Godarville (Belgique)-un exemple exceptionnel de concrétionnement moderne-intérêt pour l'étude de la cinétique de précipitation de la calcite et de sa relation avec les variations d'environnement, Spéléachronos, 4, 3-29.

Genty, D., 1993. Mise en évidence d'alternances saisonnières dans la structure interne des stalagmites. Intérêt pour la reconstitution des paléoenvironnements continentaux, C. R. Acad. Sci. Paris, 317, (II), 1229-1236.

Genty, D. and Quinif, Y., 1996. Annually laminated sequences in the internal structure of some Belgian stalagmites-importance for palaeoclimatology. 7. Sediment. Petrol., 66, 275-288.

Genty, D. and Massault, M., 1997. Bomb ${ }^{14} \mathrm{C}$ recorded in laminated speleothems: dead carbon proportion calculation. Radiocarbon, 39, 33-48.

Genty, D. and Deflandre, G., 1998. Drip flow variations under a stalactite of the Père Nöel cave (Belgium). Evidence of seasonal variations and air pressure constraints. F. Hydrol., 211, 208-232.

Genty, D., Baker, A. and Barnes, W.L., 1997. Comparison entre les lamines luminescentes et les lamines visibles de stalagmites. C. R. Acad. Sci., Paris II, 325, 193-200.

Gunn, J., 1981. Hydrological processes in karst depressions. $Z$. Geomorphologie, N.F. 25, 313-331.

Holmgren, K., Karlen, W., Lauritzen, S.E., LeeThorp, J.A., Partridge, T.C., Piketh, S., Repinski, P., Stevenson, C., Svanered, O. and Tyson, P.D., 1999. A 3000-year highresolution stalagmite-based record of palaeoclimate for northeastern South Africa. Holocene, 9, 295-309.

Huang, Y., Fairchild, I.J., Borsato, A., Frisia, S., Cassidy, N.J., McDermott, F. and Hawkesworth, C.J., 2001. Seasonal variations in $\mathrm{Sr}, \mathrm{Mg}$ and $\mathrm{P}$ in modern speleothems (Grotta di Ernesto, Italy). Chem. Geol., in press.

Kiely, G., 1997. Environmental Engineering, McGraw-Hill.

McDermott, F., Frisia, S., Huang, Y., Longinelli, A., Spiro, B., Heaton, T.H.E., Hawkesworth, C.J., Borsato, A., Keppens, E., Fairchild, I.J., van der Borg, K., Verheyden, S. and Selmo, E., 1999. Holocene climate variability in Europe: evidence from $\delta^{18} \mathrm{O}$, textural and extension-rate variations in three speleothems. Quaternary Sci. Rev., 18, 1021-1038.

McGarry, S.F. and Baker, A., 2000. Organic acid fluorescence: Applications to speleothem palaeoenvironmental reconstruction. Quaternary $S c i$. Rev., in press.

Negrel, P. and Roy, S., 1998. Chemistry of rainwater in the Massif Central (France): a strontium isotope and major element study. Appl. Geochem., 13, 941-952.

Pitty, A.F., 1971. Rate of uptake of calcium carbonate in underground karst water. Geol. Mag., 108, 537-543.

Roberts, M.S., Smart, P.L. and Baker, A., 1998. Annual trace element variations in a Holocene Speleothem. Earth Planet. Sci. Lett., 154, 237-246.

Sandberg, P.A. and Hudson, J.D., 1983. Aragonite relic preservation in Jurassic calcite-replaced bivalves. Sedimentology, 30, 879892.

Shopov, Y.Y., Ford, D.C. and Schwarcz, H.P., 1994, Luminescent 
microbanding in speleothems. High-resolution chronology and paleoclimate, Geology, 22, 407-410.

Smart, P.L. and Friedrich, H., 1987, Water movement and storage in the unsaturated zone of maturily karstified aquifer, Mendip Hills, England Proc Conf. Environ. Problems in Karst Terrains and their Solution, Bowling Green, Kentucky, 57-87.

Smart, P.L., Roberts, M.S., Baker, A and Richards, D.A, 1996. Palaeoclimate determinations from speleothens: a critical appraisal of the state of the art Proc. Conf, Climatic Change-The Kard Record, Bergen, 157-159.

Tan, M, Qin, X and LI, T, 1997 , Migrobending of stalagmite pnd its significance 7 Chase Geos, 1, 16-2s.

Thomthwite, C. W655. The Water Bdianca, Centerton, NJ. Laboretory of Climatolog, 86 Pp.

Wiliams PW, 1983. The role of the suboutaneous zone in kant hydrology. $7, H$ ydrol, $61,45-67$. 